Reply to comment

\title{
Reply to comment by C. Morhange, C. Flaux, P.A. Pirazzoli, M.B. Carre on "Holocene Sea level Change in Malta"
}

\author{
Stefano Furlani ${ }^{\text {a,b,* }}$, Fabrizio Antonioli ${ }^{c}$, Sara Biolchi ${ }^{\text {a,d }}$, Timothy Gambin ${ }^{\text {e,f }}$, \\ Ritienne Gauci ${ }^{\mathrm{e}}$, Valeria Lo Presti ${ }^{\mathrm{g}}$, Marco Anzidei ${ }^{\mathrm{h}}$, Stefano Devoto ${ }^{\mathrm{d}}$, \\ Mariarita Palombo ${ }^{\mathrm{i}}$, Attilio Sulli ${ }^{\mathrm{g}}$ \\ a Dipartimento di Matematica e Geoscienze, Università degli Studi di Trieste, Italy \\ ${ }^{\mathrm{b}}$ Dipartimento di Geografia “G. Morandini”, Università di Padova, Italy \\ ${ }^{\mathrm{c}}$ ENEA UTMEA, Roma, Italy \\ ${ }^{\mathrm{d}}$ Dipartimento di Scienze della Terra, Università degli Studi di Modena e Reggio Emilia, Modena, Italy \\ ${ }^{\mathrm{e}}$ University of Malta, Malta \\ ${ }^{\mathrm{f}}$ Aurora Trust, Malta \\ ${ }^{\mathrm{g}}$ Dipartimento di Scienze della Terra e del Mare, Università di Palermo, Italy \\ h INGV, Italy \\ i Dipartimento di Scienze della Terra, Università di Roma “La Sapienza”, Italy
}

\section{A R T I C L E I N F O}

Article history:

Available online 12 April 2013

Dear Editor, we are thankful to C. Morhange, C. Flaux, P.A. Pirazzoli and M.B. Carre for their comments to our paper: "Holocene Sea Level Change in Malta". The paper addressed reconstruction of sea level changes in the island of Malta and vertical tectonic movements during the Holocene. Based on this evidence, we proposed a reconstruction of palaeoshorelines since $20 \mathrm{ka}$ BP.

We want to underline that our aim was not that of reconstructing the sea level curve for this area, but comparing the measures collected on the submerged archaeological remains against the predicted sea level curve model suggested by Lambeck et al. (2011). In this paper, we used the only coastal archeological remains presently known in the study area. In the following section, we clarify some aspects of the results obtained and the evidence supporting our interpretation.

The pits of Birzebbugia are located near the present-day mean sea level, and some are partially submerged. They were dated using pottery discovered in an archaeological site close to the coast, dated to the Bronze Age (Zammit, 1928; Abela, 1999). As they have been interpreted as sites for the retting of flax, during their utilization they should have remained dry and the sea could not submerge them. This is the reason why these structures are not directly related to the sea level, as suggested by Biolchi et al. (2011), so they represent an upper limit.

As the pits were constructed to stay above the sea level, we estimated for the time of their construction a minimum functional

\footnotetext{
* Corresponding author. Dipartimento di Matematica e Geoscienze, Università degli Studi di Trieste, Italy.
}

elevation of $0.60 \mathrm{~m}$ above the local mean sea level (considering the local tide variations), in order to remain dry. The error bars, in this case, are relative to the functional height. As these structures were not directly related to the sea, the estimated elevation is regarded as the minimum value to keep them dry, even during high tides.

The "functional height" of an archaeological benchmark is defined as the elevation of specific architectural parts of an archaeological structure with respect to an estimated averaged sea level for a specific location at the time of their construction. Functional elevations define also the minimum elevation of the structure above the local highest tides. Lambeck et al. (2004) first introduced the basics of "functional elevation" that was later applied by Antonioli et al. (2007) and later re-explained by Auriemma and Solinas (2009). The functional heights and the possible errors are estimated on the basis of the observed indicators. These data contribute to the estimation of the intervening relative value of the sea level changes for that location (with related uncertainties represented by the error bar in the plots). See Table 1 in our text and other similar tables in other papers (Table 1 in Antonioli et al., 2007; Lambeck et al., 2004; Anzidei et al., 2011a, b; Anzidei et al., 2013, and references therein, etc.).

Finally, the Birzebbugia pits indicate a relative submersion of the southern Maltese coast. The value of $-2.68 \mathrm{~m}$ is just a predicted one, due the lack of any alternative possibility.

Cart-ruts were not used as sea level markers, but we quoted them because they are located close to the pits. According to Hughes (1999), their age is uncertain. However, Hughes (1999) studied the cart-ruts but he did not discuss the pits. 
As regards to the tanks on Manoel Island, the uncertainties in their elevation (i.e., the error bars in the plots) are related to the very sheltered environment in which the structures were found. Although we are aware that their use cannot be exactly defined, their position and archaeological hints suggest they were used for the production of garum, such as those found at Lampedusa (De Miro and Aleo Nero, 1992) and Poropalo (Bacci, 1985), so their functional elevation corresponds to the value suggested in Table 1.

Regarding the blocks at Marsaxlokk, the studied structures were slightly submerged during the Medieval Ages. They correspond to a walking surface at the past mean sea level. We used the terms "pathway" and "walking service surface" as synonymous to indicate an access to the sea. The difference in the error bars is merely a mistake in the text and we apologize for that.

The paper by Furlani et al. (2013) was not intended to establish the Holocene RSL in the Mediterranean area, especially considering the few data available for the area the authors studied. The aim was to provide new data to discuss the sea level change in Malta using for the first time some new archaeological indicators. We are aware that evidence given by these indicators is not as accurate as in other Mediterranean regions, but they represent new data for a still poorly known area. The Holocene reconstruction is instead a proposal, as reported at p. 154 "...This data allows a reliable paleogeographic reconstruction, although with some uncertainties, as the hypothesis is based on the existence of only minimal and negligible movements and sedimentary debris on the sea floor and the absence of any tectonic movements".

Considerations provided in the abstract are relative to our studies in Malta, not for other parts of the Mediterranean, because relative sea level changes are different from place to place. The fact that in other areas sea level change was different was not the object of discussion, as it is without interest for understanding what happened in the Maltese focal area. For this reason, we did not quote some interesting papers, such as Pirazzoli (1976), Devillers et al. (2007) and Goiran et al. (2009) as the authors of the comment suggest taking into account.

We disagree with the comment of Morhange et al., regarding the value of the Roman sea level. Pirazzoli (1976), Caputo and Pieri (1976), Leoni and Dai Prà (1997) provided very different values on the Roman sea level using archaeological indicators. These authors' interpretations in their studies have difficulties, because they did not work in team with marine archaeologists. Lambeck et al. (2004) for the first time presented a robust interpretation based on archaeological surveys, geological data and geophysical modeling that well fit the elevation of constructional features of the Roman fish tanks located in the central Mediterranean, at the time of their use. This study provided the guidelines for other papers dealing with the same items (i.e. Mourtzas et al., 2013; Pavlopoulos et al., 2011, among others).

In any case, it has been shown in several studies that RSLC have different values from place to place, due to glacio-hydro-isostatic effects, tectonics, volcanism and local disturbances. The sentence, "during the Roman Age, sea level was at $-1.36 \pm 0.1 \mathrm{~m}$, while in the Middle Age it was at $-0.56 \pm 0.2 \mathrm{~m}$, in agreement with previous estimations for the Mediterranean region", reminds readers of the most recent results in the Mediterranean area and shows a possible variation of the RSL in time (see also Pagliarulo et al., 2013).

Concerning the comment on the biological markers, we are aware they are excellent sea level indicators (see Lambeck et al., 2010a,b for a synthesis). Unfortunately, we did not find any of these indicators on or around the submerged archaeological remains.

\section{References}

Abela, R., 1999. Relative Sea Level Change: a Coastal Vulnerability Assessment of Malta. Unpublished thesis. University of Malta, p. 217.

Antonioli, F., Anzidei, M., Lambeck, K., Auriemma, R., Gaddi, D., Furlani, S., Orrù, P., Solinas, E., Gaspari, A., Karinja, S., Kovacic, V., Surace, L., 2007. Sea level change during Holocene from Sardinia and northeastern Adriatic (Central Mediterranean sea) from archaeological and geomorphological data. Quaternary Science Reviews 26, 2463-2486.

Anzidei, M., Antonioli, F., Benini, A., Lambeck, K., Sivan, D., Serpelloni, E., Stocchi, P., 2011a. Sea level change and vertical land movements since the last two millennia along the coasts of southwestern Turkey and Israel. Quaternary International 232, 1-8.

Anzidei, M., Antonioli, F., Lambeck, K., Benini, A., Soussi, M., Lakhdar, R., 2011b. New insights on the relative sea level change during Holocene along the coasts of Tunisia and western Libya from archaeological and geomorphological markers. Quaternary International 232 (1-2), 5-12.

Anzidei, M., Antonioli Benini, A., Gervasi, A., Guerra, I., 2013. Evidence of vertical tectonic uplift at Briatico (Calabria, Italy) inferred from Roman age maritime archaeological indicators. Quaternary International 288, 158-167.

Auriemma, R., Solinas, E., 2009. Archaeological remains as sea level change markers: a review. Quaternary International 206, 134-146.

Bacci, G.M., 1985. Scavi e Ricerche a Avola, Grammichele, Portopalo, Taormina. Kokalos 30-31, 711-725.

Biolchi, S., Gambin, T., Gauci, R., Antonioli, F., Furlani, S., Anzidei, M., Devoto, S., 2011. Late Holocene sea level change in Malta. Il Quaternario - Italian Journal of Quaternary Sciences 24, 20-22.

Caputo, M., Pieri, L., 1976. Eustatic variation in the last 2000 years in the Mediterranean. Journal of Geophysical Research 81, 5787-5790.

De Miro, A., Aleo Nero, C., 1992. Lampedusa: un impianto per la lavorazione del pesce. In: V Rassegna di archeologia subacquea, Atti, Giardini Naxos (Messina), 19-21 ottobre 1990 , pp. 45-53.

Devillers, B., Excoffon, P., Morhange, C., Bonnet, S., Bertoncello, F., 2007. Relative sealevel changes and coastal evolution at Forum Julii (Fréjus, Provence). Comptes Rendus Geoscience 339 (5), 329-336.

Furlani, S., Antonioli, F., Biolchi, S., Gambin, T., Gauci, R., Lo Presti, V., Anzidei, M., Devoto, S., Palombo, M., Sulli, A., 2013. Holocene sea level change in Malta. Quaternary International 288, 146-157.

Goiran, J.P., Tronchère, H., Collalelli, U., Salomon, F., Djerbi, H., 2009. Découverte d'un niveau marin biologique sur les quais de Portus: le port antique de Rome. Méditerranée 112, 59-67.

Hughes, K.J., 1999. Persistent features from a palaeo-landscape: the ancient tracks of the Maltese islands. The Geographical Journal 165, 62-78.

Lambeck, K., Antonioli, F., Purcell, A., Silenzi, S., 2004. Sea level change along the Italian coast for the past 10,000 yrs. Quaternary Science Reviews 23, 1567-1598.

Lambeck, K., Antonioli, F., Anzidei, M., 2010a. Sea level change along the Tyrrhenian coast from early Holocene to the present. In: Accademia Nazionale dei Lincei. Atti dei convegni Lincei 254, IX Giornata mondiale dell'acqua, Il bacino del Tevere, Roma.

Lambeck, K., Woodroffe, C.D., Antonioli, F., Anzidei, M., Gehrels, W.R., Laborel, J., Wright, A.J., 2010b. Paleoenvironmental records, geophysical modeling, and reconstruction of sea-level trends and variability on centennial and longer timescales. In: Woodworth, Philip L., Aarup, Thorkild, Stanley Wilson, W. (Eds.), Understandig Sea Level Rise and Variability. Blackwell Publishing, pp. 61-121.

Lambeck, K., Antonioli, F., Anzidei, M., Ferranti, L., Leoni, G., Scicchitano, G., Silenzi, S., 2011. Sea level change along the Italian coast during the Holocene and projections for the future. Quaternary International 232, 250-257.

Leoni, G., Dai Prà, G., 1997. Variazioni del livello del mare nel Tardo Olocene (ultimi 2500 anni), lungo la costa del Lazio, in base ad indicatori geoarcheologici, interazioni fra neotettonica, eustatismo e clima. ENEA, Dipartimento Ambiente, Centro Ricerche Casaccia, Roma. RT/AMB/97/8.

Mourtzas, N.D., Kissas, C., Kolaiti, E., 2013. Archaeological and geomorphological indicators of the historical sea level changes and the related palaeogeographical reconstruction of the ancient foreharbour of Lechaion, East Corinth Gulf (Greece). Quaternary International, 1-21,. http://dx.doi.org/10.1016/ j.quaint.2012.12.037.

Pagliarulo, R., Antonioli, F., Anzidei, M., 2013. Sea level changes since the Middle Ages along the coast of the Adriatic Sea: the case of St. Nicholas Basilica, Bari, southern Italy. Quaternary International 288, 139-145.

Pavlopoulos, K., Theodorakopoulou, K., Panagiotopoulos, I.P., 2011. Vertical displacement trends in the Aegean coastal zone (NE Mediterranean) during the Holocene assessed by geo-archaeological data. Holocene 22 (6), 717-728.

Pirazzoli, P.A., 1976. Sea level variations in the northwest Mediterranean during roman times. Science $194,519-521$.

Zammit, T., 1928. Prehistoric cart-tracks in Malta. Antiquity 2 (5), 18-25. 